\title{
ANALISIS BELANJA PEMERINTAH DAERAH KOTA BENGKULU
}

\author{
Ahmad Soleh \\ Fakultas Ekonomi Universitas Dehasen Bengkulu
}

\begin{abstract}
ABSTRAK
Ahmad Soleh; Analisis Belanja Pemerintah Daerah Kota Bengkulu. Penelitian ini bertujuan untuk menganalisis belanja ditinjau dari pertumbuhan belanja, keserasian belanja dan rasio belanja terhadap PDRB kota Bengkulu tahun 2010-2013. Penelitian ini menggunakan data sekunder berupa Laporan Realisasi Anggaran (LRA) pemerintah daerah kota Bengkulu dan data ststistik perekonomian kota Bengkulu yang bersumber dari Badan Pusat Statistik (BPS) kota Bengkulu. Teknik analisis data berupa analisis kuantitatif yaitu dengan menggunakan rumus pertumbuhan dan rasio belanja. Hasil analisis menunjukkan bahwa realisasi belanja pemerintah daerah kota Bengkulu tahun 2011-2013 mengalami fluktuasi dengan pertumbuhan rata-rata $11,76 \%$ per tahun, hal ini tidak seiring dengan pertumbuhan realisasi pendapatan yang cenderung mengalami peningkatan di setiap tahunnya. Rasio belanja operasi terhadap total belanja cenderung mengalami peningkatan dengan rata-rata sebesar $85,20 \%$ per tahun dan rasio ini mendominasi dari total pengeluaran belanja daerah sedangkan rasio belanja modal terhadap total belanja cenderung mengalami penurunan dengan rata-rata sebesar $14,78 \%$ per tahun. Rasio belanja daerah terhadap PDRB pemerintah daerah kota Bengkulu tahun 20102013 cenderung mengalami peningkatan dengan rasio rata-rata 27,04\% per tahun. Besaran nilai rasio ini juga dipengaruhi oleh nilai pertumbuhan PDRB dan total belanja. Pertumbuhan total belanja pemerintah daerah Bengkulu relatif lebih tinggi jika dibanding dengan pertumbuhan PDRB.
\end{abstract}

\begin{abstract}
Ahmad Soleh; Local Government Expenditure Analysis of Bengkulu. This study aims to analyze the expenditure in terms of spending growth, harmony expenditure and expenditure to GRDP ratio Bengkulu 2010-2013. This study uses secondary data from the Budget Realization Report from the local government of Bengkulu city and Bengkulu city's economy is sourced from the Badan Pusat Statistik (BPS) Bengkulu city. Data analysis techniques such as quantitative analysis by using the formula of growth and expenditure ratio. The analysis showed that local government spending in 2011-2013 Bengkulu city fluctuated with an average growth of $11.76 \%$ per year, this is not in line with the growth in revenue realization that tends to increase in each year. The ratio of operating expenditure to total expenditure tends to increase by an average of $85.20 \%$ per year and is the ratio of total expenditure dominates the area while the ratio of capital expenditure to total expenditure tends to decrease with an average of $14.78 \%$ per year. The ratio of government expenditure to GDP local area Bengkulu years 2010-2013 tends to increase with the average ratio of $27.04 \%$ per year. The value of this ratio is also influenced by the value of the growth of GDP and total expenditure. The growth of total government expenditure Bengkulu area is relatively higher when compared with GDP growth.
\end{abstract}

\section{Kata Kunci: Pertumbuhan Belanja, Keserasian Belanja, Rasio Belanja, Kota Bengkulu}

\section{PENDAHULUAN}

Pembangunan Daerah sebagaimana dimaksud pada ayat (1) Undang-undang Republik Indonesia Nomor 23 Tahun 2014 tentang Pemerintah Daerah merupakan perwujudan dari pelaksanaan urusan pemerintahan yang telah diserahkan ke daerah sebagai bagian integral dari pembangunan nasional. Daerah melaksanakan pembangunan untuk peningkatan dan pemerataan pendapatan masyarakat, kesempatan kerja, lapangan berusaha, meningkatkan 
akses dan kualitas pelayanan publik dan daya saing Daerah. Otonomi daerah yang dimulai pada Januari 2001 bagi setiap daerah tingkat provinsi maupun kabupaten/kota memberikan hak, wewenang, dan kewajiban daerah otonom untuk mengatur dan mengurus sendiri urusan pemerintahan dan kepentingan masyarakat setempat dalam sistem Negara Kesatuan Republik Indonesia. Pengelolaan keuangan daerah merupakan bagian yang tidak terpisahkan dari penyelenggaraan urusan pemerintahan yang menjadi kewenangan daerah sebagai akibat dari penyerahan urusan pemerintahan.

Dalam rangka pelaksanaan otonomi daerah dan desentralisasi fiskal, pemerintah daerah dituntut untuk memiliki kemampuan keuangan daerah yang lebih besar. Dengan tingkat kemandirian keuangan yang lebih besar berarti pemerintah daerah tidak akan lagi sangat tergantung pada bantuan dari pemerintah pusat dan propinsi melalui dana perimbangan. Dalam otonomi daerah terdapat dua aspek kinerja keuangan yang dituntut agar lebih baik dibandingkan sebelum otonomi daerah. Aspek pertama adalah bahwa daerah diberi kewenangan mengurus pembiayaan daerah dengan kekuatan utama pada kemampuan Pendapatan Asli Daerah (Desentralisasi Fiskal). Aspek kedua yaitu di sisi manajemen pengeluaran daerah, bahwa pengelolaan keuangan daerah harus lebih akuntabel dan transparan tentunya menuntut daerah agar lebih efisien dan efektif dalam pengeluaran daerah. Kedua aspek tersebut dapat disebut sebagai reformasi pembiayaan atau Financing Reform. Pembiayaan suatu daerah diperoleh dari Anggaran Pendapatan Belanja Daerah (APBD) yang disusun setiap tahun oleh pemerintah daerah beserta satuan kerjanya guna memenuhi pelayanan publik.

Berdasar laporan realisasi anggaran pendapatan dan belanja daerah kota Bengkulu tahun 2010-2013, menunjukkan bahwa realisasi pendapatan dan belanja pemerintah kota Bengkulu cenderung mengalami peningkatan. Struktur pendapatan kota Bengkulu didominasi oleh pendapatan transfer. Laporan realisasi anggaran pendapatan dan belanja daerah kota Bengkulu tahun 2013 menunjukkan bahwa pendapatan transfer memberi kontribusi sebesar 92,29\% sedangkan Pendapatan Asli Daerah (PAD) memberi kontribusi sebesar 7,05\% dan sisanya adalah $0,65 \%$ bersumber dari lain-lain pendapatan yang sah. Sedangkan jika dilihat dari sisi belanja, struktur belanja pemerintah kota Bengkulu didominasi oleh belanja operasi. Tahun 2013, total belanja operasi mencapai $83,57 \%$ sedangkan belanja modal sebesar $16,42 \%$ dan transfer sebesar 2,56\%. Pemerintah kota Bengkulu memiliki rata-rata surplus pendapatan sebesar 27.088.312.616,38 rupiah per tahun.

Analisis belanja daerah sangat penting dilakukan untuk mengevaluasi apakah pemerintah daerah telah menggunakan APBD secara ekonomis, efisien dan efektif (value for money). Sejauh mana pemerintah daerah telah melakukan efisiensi anggaran, menghindari pengeluaran yang tidak perlu dan pengeluaran yang tidak tepat sasaran. Pemerintah tidak perlu lagi berorientasi untuk menghabiskan anggaran yang berakibat terjadinya pemborosan anggaran melainkan berorientasi pada output dan outcome dari anggaran (Mahmudi, 2010). Analisis pertumbuhan belanja daerah memberi informasi perkembangan belanja dari tahun ke tahun, analisis keserasian belanja akan memberikan informasi tentang keseimbangan antar belanja sedangkan rasio belanja daerah terhadap PDRB akan menunjukkan produktivitas dan efisiensi belanja daerah.

Argumentasi di atas menjadi dasar perumusan masalah dalam penelitian ini yaitu bagaimana belanja pemerintah daerah Kota Bengkulu ditinjau dari pertumbuhan belanja, keserasian belanja dan rasio belanja daerah terhadap PDRB tahun 2010-2013?. Sedangkan tujuan penelitian ini adalah untuk menganalisis pertumbuhan belanja, keserasian belanja dan rasio belanja daerah terhadap PDRB kota Bengkulu tahun 2010-2013.

\section{LANDASAN TEORI}

\section{Laporan Keuangan Pemerintrah Daerah}

Menurut Mahmudi (2010) laporan keuangan adalah informasi yang disajikan untuk membantu stakeholders dalam membuat keputusan sosial, politik, dan ekonomi sehingga 
keputusan yang diambil bisa lebih berkualitas. Terdapat alasan utama mengapa pemerintah daerah perlu mempublikasikan laporan keuangan yaitu:

a. Dari sisi internal, laporan keuangan merupakan alat pengendalian dan evaluasi kinerja bagi pemerintah daerah secara keseluruhan maupun unit-unit kerja di dalamnya (Satuan kerja Perangkat daerah). Laporan keuangan merupakan bentuk pertanggungjawaban internal yaitu pertanggungjawaban kepala satuan kerja kepada kepala daerah, kepala daerah kepada pegawai pemda dan DPRD.

b. Dari sisi pemakai eksternal, laporan keuangan pemerintah daerah merupakan bentuk pertanggungjawaban eksternal yaitu pertanggungjawaban kepala daerah kepada masyarakat, investor, kreditor, lembaga donor, pers, serta pihak-pihak lain yang berkepentingan dengan laporan tersebut sebagai dasar untuk pengambilan keputusan ekonomi, sosial dan politik.

Jenis laporan keuangan pokok yang harus dibuat pemerintah daerah meliputi (1) Neraca, (2) Laporan Realisasi Anggaran (LRA), (3) Laporan Arus Kas (LAK), (4) Catatan Atas Laporan Keuangan (CaLK), dan (5) Lampiran: Laporan keuangan BUMD. Dalam penelitian ini jenis laporan keuangan yang digunakan adalah Laporan Realisasi Anggaran (LRA) yang terdiri atas empat elemen (pos) utama yaitu (1) Pendapatan, (2) Belanja, (3) Transfer, (4) Surplus/Defisit, (5) Pembiayaan, dan (6) SiLPA (SiKPA) dan dari ke enam elemen tersebut elemen yang digunakan adalah pendapatan dan belanja.

\section{Pendapatan dan Belanja Daerah}

Standar Akuntansi Pemerintahan (SAP) mendefinisikan pendapatan sebagai semua penerimaan Rekening Kas Umum Negara/Daerah yang menambah ekuitas dana lancar dalam periode tahun anggaran bersangkutan yang menjadi hak pemerintah dan tidak perlu dibayar kembali oleh pemerintah. Secara umum pendapatan daerah dapat dipahami sebagai hak pemerintah daerah yang menambah kekayaan bersih yang terjadi akibat transaksi masa lalu. Pendapatan pemerintah daerah berbeda dengan penerimaan daerah. Penerimaan daerah adalah semua jenis penerimaan kas yang masuk ke rekening kas daerah baik yang murni berasal dari pendapatan daerah maupun dari penerimaan pembiayaan. Menurut Undangundang Republik Indonesia Nomor 23 Tahun 2014 tentang Pemerintah Daerah, pendapatan daerah adalah semua hak daerah yang diakui sebagai penambah nilai kekayaan bersih dalam periode tahun anggaran yang bersangkutan. Sumber pendapatan daerah terdiri atas (a) Pendapatan Asli Daerah meliputi pajak daerah; retribusi daerah; hasil pengelolaan kekayaan daerah yang dipisahkan; dan lain-lain Pendapatan Asli Daerah yang sah; (b) Pendapatan transfer; dan (c) Lain-lain pendapatan daerah yang sah.

Berdasarkan standar akuntansi pemerintahan, belanja daerah dapat didefinisikan sebagai semua pengeluaran dari rekening kas umum daerah yang mengurangi ekuitas dana lancar dalam periode tahun anggaran bersangkutan yang tidak akan diperoleh pembayarannya kembali oleh pemerintah daerah. Belanja dapat dipahami sebagai kewajiban pemerintah daerah yang mengurangi kekayaan bersih yang terjadi akibat transaksi masa lalu. Namun dalam hal ini perlu dipahami bahwa belanja daerah berbeda dengan pengeluaran daerah. Tidak semua pengeluaran yang dilakukan pemerintah daerah yang menyebabkan berkurangnya kas di rekening kas umum daerah dikategorikan sebagai belanja. Namun setiap belanja merupakan pengeluaran pemerintah daerah. Pengeluaran pemerintah daerah dapat berupa belanja atau bisa juga merupakan pengeluaran pembiayaan. Kedua jenis pengeluaran ini baik belanja daerah maupun pengeluaran pembiayaan sama-sama membutuhkan bukti pengeluaran kas. Perbedaannya adalah untuk pengeluaran pembiayaan membutuhkan bukti pendukung berupa bukti memorial dan perlu persetujuan DPRB (Mahmudi, 2010). Menurut Undang-undang Republik Indonesia Nomor 23 Tahun 2014 tentang Pemerintah Daerah, belanja daerah adalah semua kewajiban daerah yang diakui sebagai pengurang nilai kekayaan bersih dalam periode tahun anggaran yang bersangkutan. Definisi lain dari belanja ini adalah seperti yang di jelaskan dalam peraturan Menteri Dalam Negeri No. 13 Tahun 2006, belanja adalah kewajiban pemerintah daerah yang diakui sebagai pengurang nilai kekayaan bersih. Sedangkan belanja di lingkungan akuntansi pemerintahan di Indonesia diartikan sebagai semua pengeluaran 
bendahara umum negara/ daerah yang mengurangi ekuitas dana lancar dalam periode tahun anggaran yang bersangkutan yang tidak akan diperoleh kembali pembayarannya oleh pemerintah (Nordiawan, 2007).

\section{Analisis Pertumbuhan Belanja}

Analisis pertumbuhan belanja bermanfaat untuk mengetahui perkembangan belanja dari tahun ke tahun. Pada umumnya belanja memiliki kecenderungan untuk selalu naik. Alasan kenaikan belanja biasanya dikaitkan dengan penyesuaian terhadap inflasi, perubahan kurs rupiah, perubahan jumlah cakupan layanan, dan penyesuaian faktor makro ekonomi. Dalam penyelenggaraan otonomi daerah, pemerintah daerah harus dapat mengendalikan belanja daerah, melakukan efisiensi belanja dan penghematan anggaran. Analisis pertumbuhan belanja dilakukan untuk mengetahui berapa besar pertumbuhan masing-masing belanja, apakah pertumbuhan tersebut rasional dan dapat dipertanggungjawabkan. Pertumbuhan belanja harus diikuti dengan pertumbuhan pendapatan yang seimbang, sebab jika tidak maka dalam jangka menengah dapat mengganggu kesinambungan dan kesehatan fiskal daerah. Pertumbuhan belanja daerah dapat dihitung dengan menggunakan rumus (Mahmudi, 2010):

\section{Pertumbuhan Belanja Tahun t$$
=\frac{\text { Realisasi BelanjaThn } t-\text { Realisasi BelanjaThn } t-1}{\text { Realisasi BelanjaThn } t-1} \times 100 \%
$$

\section{Analisis Keserasian Belanja}

Menurut Mahmudi (2010) analisis keserasian belanja bermanfaat untuk mengetahui keseimbangan antar belanja. Hal ini terkait dengan fungsi anggaran sebagai alat distribusi. Analisis keserasian belanja antara lain berupa:

a. Analisis Belanja Operasi terhadap Total Belanja.

Analisis belanja operasi terhadap total belanja merupakan perbandingan antara total belanja operasi dengan total belanja daerah. Belanja operasi merupakan belanja yang manfaatnya habis dikonsumsi dalam satu tahun anggaran, sehingga belanja operasi ini sifatnya jangka pendek dan dalam hal tertentu sifatnya rutin atau berulang (recurrent). Pada umumnya proporsi belanja operasi mendominasi total belanja daerah, yaitu antara 60-90 persen. Pemerintah daerah dengan tingkat pendapatan daerah tinggi cenderung memiliki porsi belanja operasi belanja yang lebih tinggi dibandingkan pemerintah daerah yang tingkat pendapatanya rendah. Rasio belanja operasi terhadap total belanja dirumuskan sebagai berikut:

\section{Rasio Belanja Operasi terhadap Total Belanja $=\frac{\text { Realisasi Belanja Operasi }}{\text { Total Belanja Daerah }} \times 100 \%$}

b. Analisis Belanja Modal terhadap Total Belanja.

Analisis belanja modal terhadap total belanja merupakan perbandingan antara total realisasi belanja modal dengan total belanja daerah. Berdasar laporan ini, akan diketahui porsi belanja daerah yang dialokasikan untuk investasi dalam bentuk belanja modal pada tahun anggaran bersangkutan. Pengeluaran belanja modal akan memberi manfaat dalam jangka menengah dan panjang. Belanja modal akan mempengaruhi neraca pemerintah daerah yaitu menambah jumlah asset daerah. Pemerintah daerah dengan tingkat pendapatan daerah yang rendah memiliki porsi jumlah belanja modal yang tinggi dibandingkan pemerintah daerah dengan pendapatan tinggi. Hal ini disebabkan pemerintah daerah dengan tingkat pendapatan rendah berorientasi untuk melakukan belanja modal sebagai bagian dari investasi modal jangka panjang, sedangkan pemerintahan yang berpendapatan tinggi biasanya telah memiliki asset modal yang mencukupi. Pada umumnya proporsi belanja modal terhadap total belanja daerah antara 5-20 persen. Rasio belanja modal terhadap total belanja dirumuskan sebagai berikut: 
Rasio Belanja Modal terhadap Total Belanja $=\frac{\text { Realisasi Belanja Modal }}{\text { Total Belanja Daerah }} \times 100 \%$

\section{Rasio Belanja Daerah Terhadap PDRB}

Rasio belanja daerah terhadap PDRB merupakan perbandingan antara total belanja daerah dengan PDRB yang dihasilkan daerah. Rasio ini menunjukkan produktifitas dan efektivitas belanja daerah. Rasio ini dirumuskan sebagai berikut:

Rasio Belanja Daerah terhadap PDRB $=\frac{\text { Total Realisasi Belanja Daerah }}{\text { Total PDRB }} \times 100 \%$

\section{KERANGKA ANALISIS}

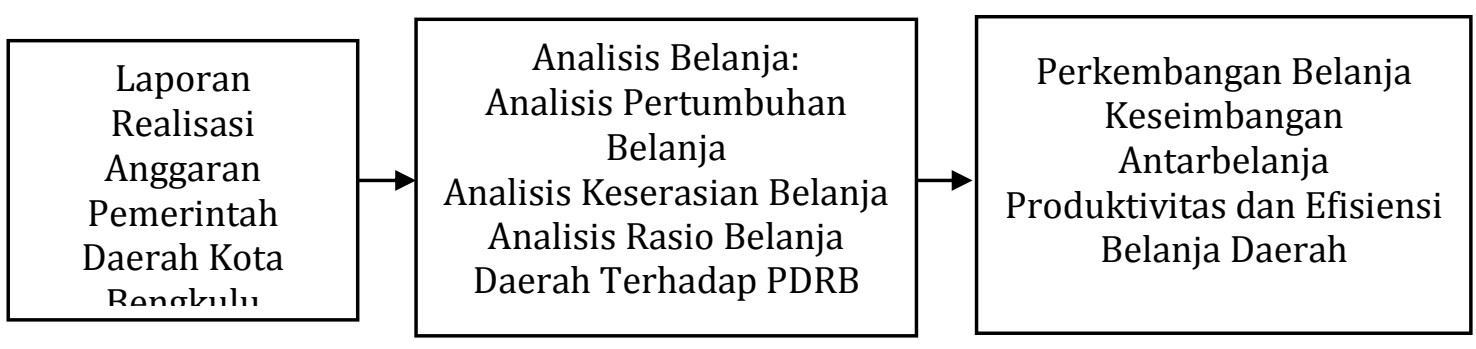

Gambar 1. Kerangka Analisis

\section{PEMBAHASAN}

\section{Perekonomian Kota Bengkulu}

Pertumbuhan ekonomi adalah salah satu indikator yang dapat digunakan untuk mengevaluasi keberhasilan pembangunan ekonomi suatu wilayah. Pertumbuhan ekonomi suatu wilayah menggambarkan sejauh mana aktivitas perekonomian suatu wilayah dalam menghasilkan tambahan pendapatan masyarakat pada periode tertentu. Sedangkan aktivitas perekonomian merupakan suatu proses penggunaan faktor produksi untuk menghasilkan output. Proses penggunaan faktor produksi akan menghasilkan balas jasa. Oleh karena itu dengan adanya pertumbuhan ekonomi diharapkan pendapatan masyarakat meningkat, sebab masyarakat adalah pemilik faktor produksi. Pertumbuhan ekonomi dihitung berdasarkan PDRB atas dasar harga konstan 2000. Selama kurun waktu tahun 2010 hingga tahun 2013, pertumbuhan ekonomi kota Bengkulu mengalami fluktuasi. Penurunan pertumbuhan ekonomi terjadi pada tahun 2011 yaitu sebesar $0,25 \%$ dari tahun sebelumnya, sedangkan pada tahun 2012 pertumbuhan ekonomi mengalami peningkatan yaitu sebesar 6,30\% hingga pada tahun 2013 pertumbuhan ekonomi kembali mengalami peningkatan yaitu sebesar 6,44\% dan ratarata pertumbuhan ekonomi kota Bengkulu tahun 2010-2013 sebesar 6,33\% per tahun.

Gambar 2. Pertumbuhan Ekonomi Kota Bengkulu Tahun 2010-2013

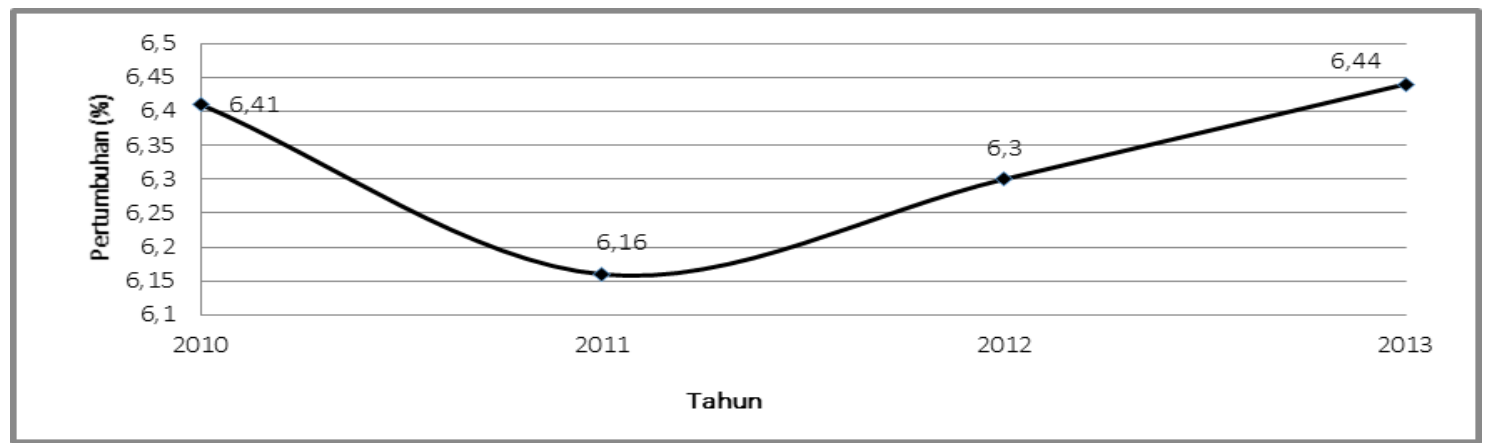

Sumber: Kota Bengkulu Dalam Angka, 2014 
Struktur ekonomi dipergunakan untuk menunjukkan komposisi atau susunan sektorsektor ekonomi dalam suatu perekonomian. Sektor yang dominan atau yang diandalkan mempunyai kedudukan yang paling atas dalam struktur tersebut menjadi ciri khas suatu perekonomian. Sektor ekonomi yang dominan adalah sektor ekonomi yang menjadi sumber mata pencaharian sebagian besar penduduk serta menjadi penyerap tenaga kerja yang besar. Dapat juga dikatakan sektor yang memberikan kontribusi yang terbesar terhadap produk nasional dengan laju pertumbuhan yang tinggi, yang menjadi ciri khas perekonomian. Untuk menggambar struktur perekonomian dimaksud, berikut disajikan Produk Domestik Bruto atas dasar harga konstan 2000 yang menggambarkan kondisi perekonomian pada tahun 2010-2013 di Kota Bengkulu. Tabel 1 menggambarkan kontribusi masing-masing sektor ekonomi terhadap pembentukan Produk Domestik Regional Bruto (PDRB) kota Bengkulu tahun 2010-2013. Secara umum, kontribusi masing-masing sektor mengalami peningkatan. Sektor yang memberikan kontribusi yang tinggi terhadap pembentukan PDRB adalah sektor perdagangan, hotel dan restoran. Selama periode pengamatan, sektor ini memberikan kontribusi rata-rata sebesar $830.490,52$ juta rupiah. Sedangkan sektor yang memberikan kontribusi terendah adalah sektor pertambangan dan penggalian. Selama periode pengamatan, sektor ini memberikan kontribusi rata-rata sebesar $12.529,45$ juta rupiah.

Tabel 1 Produk Domestik Bruto Atas Dasar Harga Konstan 2000 Menurut Lapangan Usaha (Miliar Rupiah) Tahun 2010-2013

\begin{tabular}{|c|c|c|c|c|}
\hline \multirow{2}{*}{ LAPANGAN USAHA } & \multicolumn{4}{|c|}{ Tahun } \\
\hline & 2010 & 2011 & 2012 & 2013 \\
\hline $\begin{array}{l}\text { 1. Pertanian, Peternakan, Kehutanan \& } \\
\text { Perikanan }\end{array}$ & $117,219.60$ & $119,366.52$ & $123,152.84$ & $125,149.57$ \\
\hline 2. Pertambangan dan Penggalian & $12,162.17$ & $12,158.25$ & $12,836.65$ & $12,960.73$ \\
\hline 3. Industri Pengolahan & $94,785.96$ & $100,870.83$ & $106,370.57$ & $113,292.07$ \\
\hline 4. Listrik, Gas dan Air Bersih & $19,517.82$ & $19,846.33$ & $20,890.64$ & $21,909.70$ \\
\hline 5. Konstruksi & $82,494.36$ & $87,273.61$ & $94,833.61$ & $98,806.12$ \\
\hline 6. Perdagangan, Hotel dan Restoran & $748,624.72$ & $797,613.80$ & $855,379.26$ & $920,344.29$ \\
\hline 7. Pengangkutan dan Komunikasi & $363,217.24$ & $382,401.67$ & $398,604.04$ & $422,558.27$ \\
\hline 8. Keuangan, Real Estat dan Jasa Perusahaan & $193,239.89$ & $206,303.23$ & $217,910.04$ & $230,046.58$ \\
\hline 9. Jasa-Jasa & $498,593.49$ & $535,155.15$ & $573,415.74$ & $613,200.78$ \\
\hline PDRB Kota Bengkulu & $2,129,855.25$ & $2,206,989.39$ & $2,403,393.39$ & $2,558,268.11$ \\
\hline
\end{tabular}

Sumber: Kota Bengkulu Dalam Angka, 2014

\section{Realisasi Pendapatan dan Belanja Pemerintah Daerah Kota Bengkulu}

Secara umum Anggaran Pendapatan dan Belanja Daerah (APBD) terdiri dari pendapatan daerah, belanja daerah dan pembiayaan daerah. Pendapatan daerah terdiri dari Pendapatan Asli Daerah (PAD), pendapatan transfer dan lain-lain pendapatan yang sah. Selanjutnya belanja daerah terdiri dari belanja operasi, belanja modal, belanja tak terduga dan transfer sedangkan pembiayaan daerah terdiri dari penerimaan pembiayaan dan pengeluaran pembiayaan. Realisasi pendapatan dan belanja pemerintah daerah kota Bengkulu tahun 2010-2013 ditunjukkan pada gambar 3. 
Gambar 3. Realisasi Pendapatan dan Belanja Pemerintah Daerah Kota Bengkulu Tahun 20102013

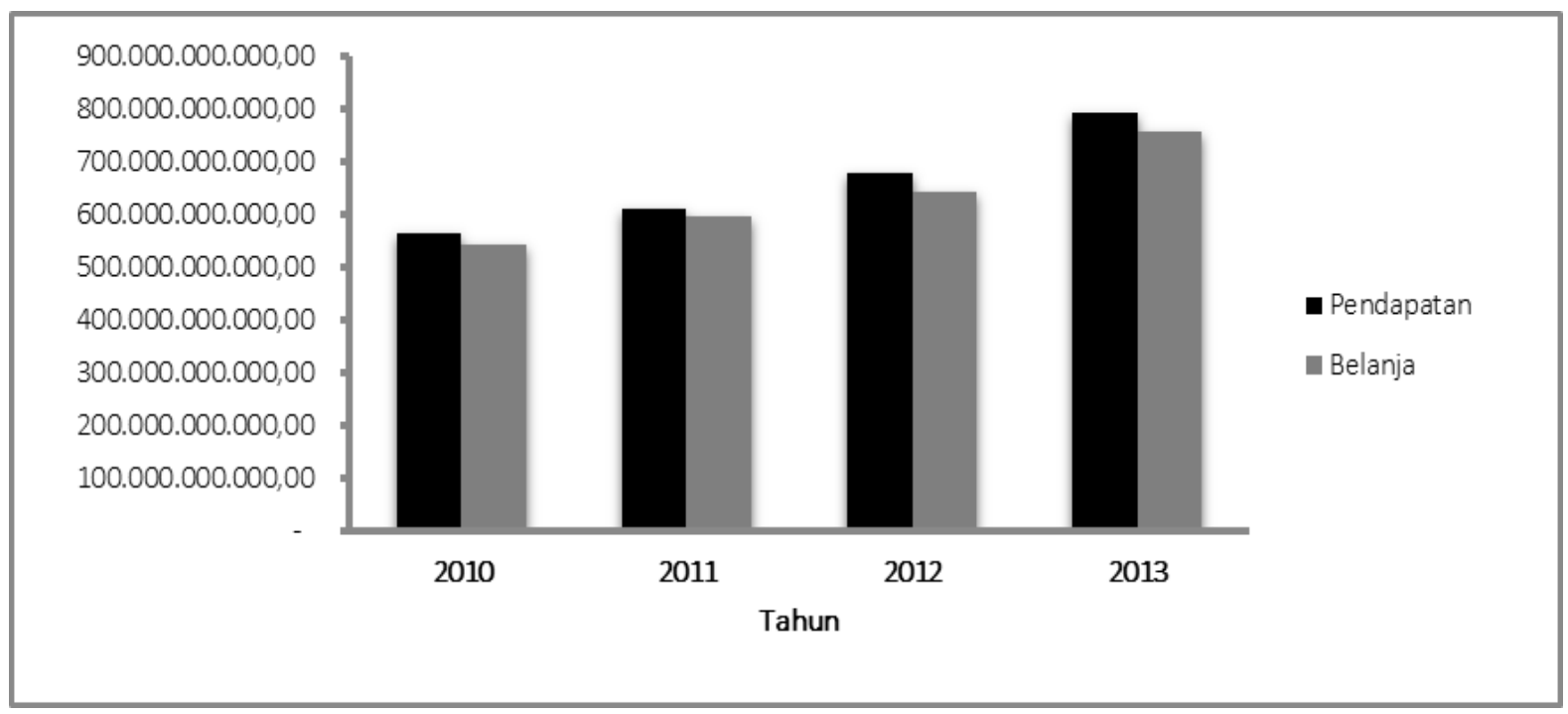

Berdasar gambar 3 diketahui bahwa realisasi pendapatan dan belanja pemerintah daerah kota Bengkulu dari Tahun Anggaran 2010 hingga Tahun Anggaran 2013 cenderung mengalami peningkatan. Pendapatan rata-rata sebesar Rp 661.557.263.758,95 per tahun. Komposisi pendapatan pemerintah daerah kota Bengkulu didominasi oleh pendapatan transfer. Seperti data LRA tahun 2013 menunjukkan bahwa pendapatan transfer memberi kontribusi sebesar Rp 732.376.234.709,57 atau sebesar 92,29\% dari total pendapatan sedangkan Pendapatan Asli Daerah (PAD) memberi kontribusi sebesar Rp 55.979.830.260,46 (7,05\%) dan sisanya adalah Rp 5.150.000.000,00 (0,65\%) bersumber dari lain-lain pendapatan yang sah.

Ditinjau dari sisi belanja, selama kurun waktu 2010-2013 pemerintah daerah kota Bengkulu memiliki belanja rata-rata sebesar Rp 634.468.951.142,57 per tahun. Realisasi belanja selalu lebih rendah dari total pendapatan, sehingga memiliki surplus rata-rata sebesar $\mathrm{Rp}$ 27.088.312.616,38 per tahun. Belanja Operasi memiliki porsi tertinggi atas realisasi total belanja di kota Bengkulu. Selama kurun waktu tahun 2010-2013, rata-rata belanja operasi sebesar Rp 541.064.504.259,50 (85,28\%) per tahun, rata-rata belanja modal sebesar Rp 93.286.476.153,07 (14,70\%) per tahun, rata-rata belanja tak terduga sebesar Rp 91.876.000,00 $(0,014 \%)$ per tahun dan rata-rata transfer sebesar $26.094 .730,00(0,004 \%)$ per tahun.

\section{Analisis Pertumbuhan Belanja Pemerintah Daerah Kota Bengkulu}

Analisis pertumbuhan belanja bermanfaat untuk mengetahui perkembangan belanja dari tahun ke tahun. Analisis pertumbuhan belanja dilakukan untuk mengetahui berapa besar pertumbuhan masing-masing belanja, apakah pertumbuhan tersebut rasional dan dapat dipertanggungjawabkan. Pertumbuhan pendapatan dan belanja pemerintah daerah Kota Bengkulu tahun 2011-2013 ditunjukkan pada tabel berikut: 
Tabel 2 Pertumbuhan Pendapatan dan Belanja Pemerintah Daerah Kota Bengkulu Tahun 20112013

\begin{tabular}{lccc} 
& URAIAN & \multicolumn{2}{c}{ PERTUMBUHAN BELANJA (\%) } \\
& $\mathbf{2 0 1 1}$ & $\mathbf{2 0 1 2}$ & $\mathbf{2 0 1 3}$ \\
& & & $\mathbf{1 7 . 1 7}$ \\
PENDAPATAN & $\mathbf{8 . 5 4}$ & $\mathbf{1 0 . 6 9}$ & \\
BELANJA OPERASI & & & 12.21 \\
Belanja Pegawai & & & 42.33 \\
Belanja Barang & 12.89 & 13.35 & $(81.25)$ \\
Belanja Hibah & 26.25 & $(9.61)$ & $(63.18)$ \\
Belanja Bantuan Sosial & 40.00 & 244.82 & $(89.62)$ \\
Belanja Bantuan Keuangan & 26.54 & $(2.22)$ & $\mathbf{9 . 2 5}$
\end{tabular}

\section{BELANJA MODAL}

Belanja Tanah

Belanja Peralatan dan Mesin

Belanja Gedung dan Bangunan

Belanja Jalan, Irigasi dan Jaringan

Belanja Aset Tetap Lainnya

Jumlah Belanja Modal

BELANJA TAK TERDUGA

Belanja Tak Terduga

Jumlah Belanja Tak Terduga

TRANSFER

TOTAL BELANJA

$\begin{array}{ccc}1,102.77 & (86.10) & (100.00) \\ \mathbf{1 , 1 0 2 . 7 7} & (\mathbf{8 6 . 1 0 )} & (\mathbf{1 0 0 . 0 0 )} \\ \mathbf{3 2 . 4 8} & \mathbf{4 3 . 5 4} & (\mathbf{4 9 . 1 7 )}) \\ \mathbf{9 . 5 2} & \mathbf{7 . 9 1} & \mathbf{1 7 . 8 5}\end{array}$

Berdasar tabel 2 diketahui bahwa pertumbuhan pendapatan pemerintah daerah kota Bengkulu tahun 2011-2013 cenderung mengalami peningkatan dan memiliki rata-rata pertumbuhan pendapatan sebesar $12,13 \%$ per tahun. Peningkatan ini seiring dengan peningkatan pendapatan yang diterima oleh pemerintah daerah kota Bengkulu beberapa tahun terakhir. Sedangkan pertumbuhan total belanja mengalami fluktuasi, tahun 2011 pertumbuhan total belanja mencapai 9,52 persen, tahun 2012 mengalami penurunan sebesar 1,61\% dari tahun sebelumnya atau memiliki pertumbuhan sebesar 7,91\% sedangkan pada tahun 2013 pertumbuhan total belanja kembali mengalami peningkatan menjadi $17,85 \%$. Selama periode pengamatan, realisasi total belanja pemerintah daerah kota Bengkulu selalu lebih rendah dari realisasi pendapatan yang diterima, sehingga pemerintah daerah kota Bengkulu selalu mengalami surplus dengan nilai $\mathrm{Rp}$ 27.088.312.616,38 per tahun. Tahun 2011, surplus anggaran pemerintah daerah kota Bengkulu mengalami pertumbuhan negatif yaitu sebesar $17,97 \%$ atau terjadi penurunan surplus dari nilai $\mathrm{Rp} 20.232 .254 .452,62$ pada tahun 2010 menjadi Rp 16.596.534.104,27 pada tahun 2011. Tahun 2012, surplus anggaran mengalami peningkatan yang cukup tinggi yakni mencapai Rp 34.945.293.912,59 sehingga mengalami pertumbuhan sebesar $110,56 \%$ sedangkan pada tahun 2013, surplus anggaran masih mengalami pertumbuhan meskipun memiliki nilai yang relatif lebih kecil yakni sebesar 4,68\%.

Realisasi total belanja operasi pemerintah daerah kota Bengkulu dari tahun 2010-2013 cenderung mengalami peningkatan, namun pertumbuhan total belanja operasi cenderung mengalami penurunan dan memiliki rata-rata pertumbuhan sebesar 12,92\% per tahun. Belanja 
pegawai merupakan salah satu unsur belanja operasi yang memiliki pertumbuhan yang relatif stabil jika dibanding dengan unsur yang lain. Unsur belanja ini juga memberikan kontribusi yang paling tinggi jika dibanding dengan unsur yang lain. Rata-rata kontribusi belanja pegawai mencapai $76,58 \%$ per tahun. Tahun 2012, belanja hibah memiliki pertumbuhan yang sangat tinggi yakni mencapai $244,82 \%$, hal tersebut disebabkan oleh realisasi belanja hibah tahun 2012 cukup tinggi jika dibanding dengan tahun 2010, 2011 dan 2013.

Rata-rata pertumbuhan realisasi belanja modal pemerintah daerah kota Bengkulu tahun 2010-2013 adalah 17,66\% per tahun. Dari tahun 2010-2012 realisasi belanja modal cenderung mengalami penurunan, hal tersebut menyebabkan pertumbuhan realisasi belanja modal tahun 2011-2012 menjadi negatif yakni masing-masing adalah $-20,71 \%$ dan $-23,11 \%$. Selanjutnya pada tahun 2013 realisasi belanja modal meningkat cukup tinggi dari nilai Rp 63.152.680.636,28 pada tahun 2012 menjadi Rp 124.277.386.287,00 pada tahun 2013 sehingga pertumbuhan belanja modal mencapai $96,79 \%$. Tingginya pertumbuhan belanja modal pada tahun 2013 juga merupakan kontribusi atas pertumbuhan positif masing-masing unsur dalam total belanja modal.

Pertumbuhan belanja tak terduga memiliki rata-rata yang sangat tinggi yakni mencapai $305,56 \%$ per tahun. Tingginya nilai tersebut lebih disebabkan pada peningkatan belanja tak terduga pada tahun 2011 yakni mencapai $\mathrm{Rp} 300.693 .000,00$ dari nilai $\mathrm{Rp} 25.000 .000,00$ sehingga pada tahun 2011 pertumbuhan mencapai 1.102,77\%. Namun pada tahun 2012 realisasi belanja tak terduga kembali menurun menjadi $\mathrm{Rp} 41.811 .000,00$ atau dengan pertumbuhan negatif sebesar $-86,10 \%$ dan pada tahun 2013 realisasi belanja tak terduga adalah nol (0) sehingga pertumbuhan menjadi $-100 \%$ dari tahun sebelumnya. Selanjutnya pertumbuhan jumlah transfer juga mengalami fluktuasi, tahun 2011 memiliki pertumbuhan sebesar 32,48\%, tahun 2012 meningkat menjadi 43,54 dan tahun 2013 mengalami penurunan yakni dengan pertumbuhan sebesar $-49,17 \%$.

\section{Analisis Keserasian Belanja Pemerintah Daerah Kota Bengkulu}

Analisis keserasian belanja bermanfaat untuk mengetahui keseimbangan antar belanja. Hal ini terkait dengan fungsi anggaran sebagai alat distribusi. Rasio belanja operasi dan belanja modal terhadap total belanja pemerintah daerah kota Bengkulu tahun 2010-1013 ditunjukkan pada gambar 4. Dari gambar tersebut diketahui bahwa trend rasio belanja operasi terhadap total belanja memiliki arah yang bererlawanan dengan trend rasio belanja modal terhadap total belanja.

Gambar 4. Rasio belanja operasi dan belanja modal terhadap total belanja pemerintah daerah kota Bengkulu tahun 2010-1013

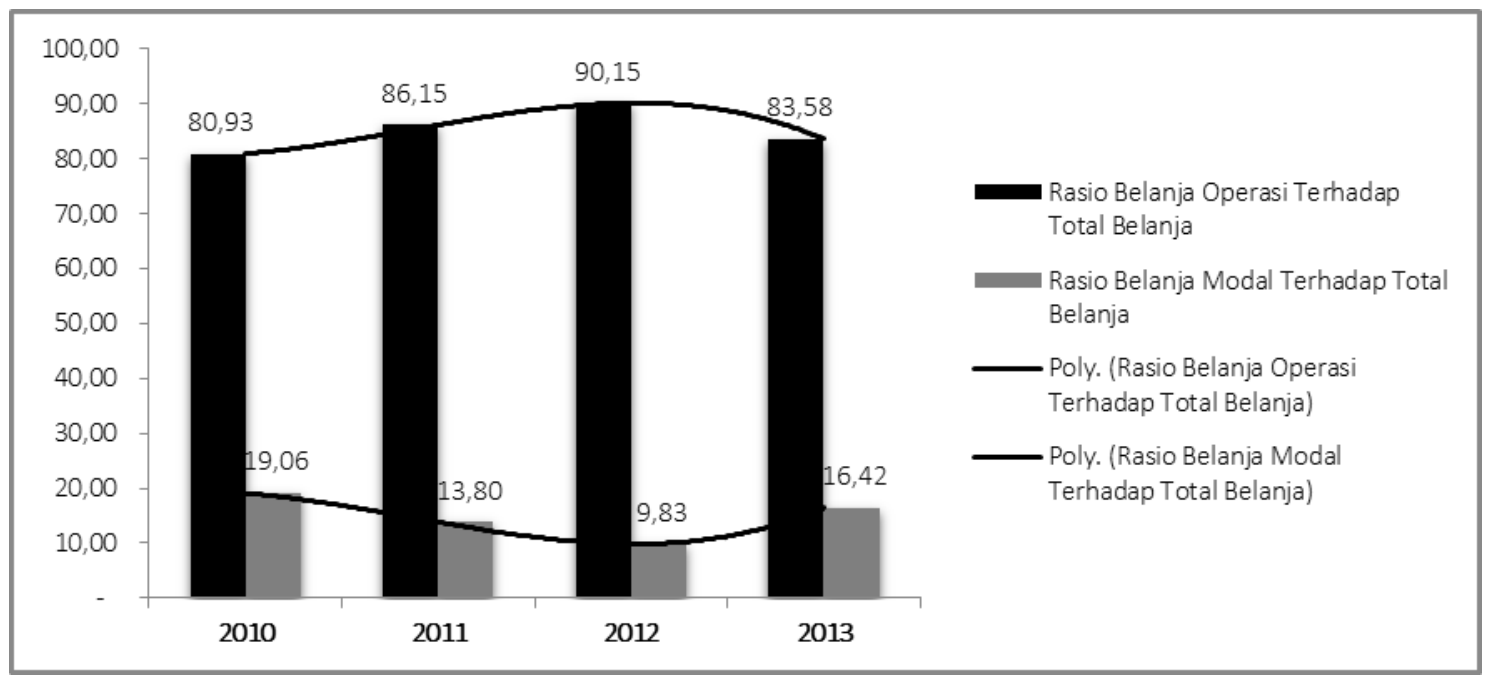


a. Analisis Belanja Operasi terhadap Total Belanja.

Secara umum proporsi belanja operasi mendominasi total belanja daerah, yaitu antara $60 \%$ 90\%. Pemerintah daerah kota Bengkulu dari tahun 2010-2013 memiliki rata-rata rasio belanja operasi terhadap total belanja sebesar 85,20\%. Tahun 2010-2012, trend rasio belanja operasi terhadap total belanja cenderung meningkat, namun pada tahun 2013 nilai rasio ini mengalami penurunan, sedangkan rasio belanja modal terhadap total belanja mengalami peningkatan. Semakin tinggi pendapatan pemerintah daerah kota Bengkulu, maka akan dapat meningkatkan total belanja operasi. Belanja ini merupakan merupakan belanja yang manfaatnya habis dikonsumsi dalam satu tahun anggaran, sehingga belanja operasi ini sifatnya jangka pendek dan dalam hal tertentu sifatnya rutin atau berulang (recurrent).

b. Analisis Belanja Modal terhadap Total Belanja.

Secara umum proporsi belanja modal terhadap total belanja daerah antara 5\% - 20\%. Pemerintah daerah kota Bengkulu dari tahun 2010-2013 memiliki rata-rata rasio belanja modal terhadap total belanja sebesar $14,78 \%$. Trend rasio ini berbanding terbalik dengan trend rasio belanja operasi terhadap total belanja. Secara umum kecenderungan rasio ini memiliki trend yang semakin menurun, hanya pada tahun 2013 mengalami peningkatan. Pemerintah daerah kota Bengkulu masih memfokuskan pada investasi penyediaan infrastruktur jalan, hal ini tercermin dalam realisasi penggunaan belanja modal di pemerintah daerah kota Bengkulu yang masih didominasi oleh pengeluaran untuk belanja jalan, irigasi dan jaringan dengan rata-rata pengeluaran mencapai 52,04\% per tahun.

\section{Rasio Belanja Daerah Terhadap PDRB Pemerintah Daerah Kota Bengkulu}

Rasio belanja daerah terhadap PDRB merupakan perbandingan antara total belanja daerah dengan PDRB yang dihasilkan daerah. Rasio ini menunjukkan produktifitas dan efektivitas belanja daerah. Rasio belanja daerah terhadap PDRB (atas dasar harga konstan 2000) pemerintah daerah kota Bengkulu tahun 2010-2013 ditunjukkan pada gambar 5.

Gambar 5. Rasio belanja daerah terhadap PDRB pemerintah daerah kota Bengkulu tahun 20102013

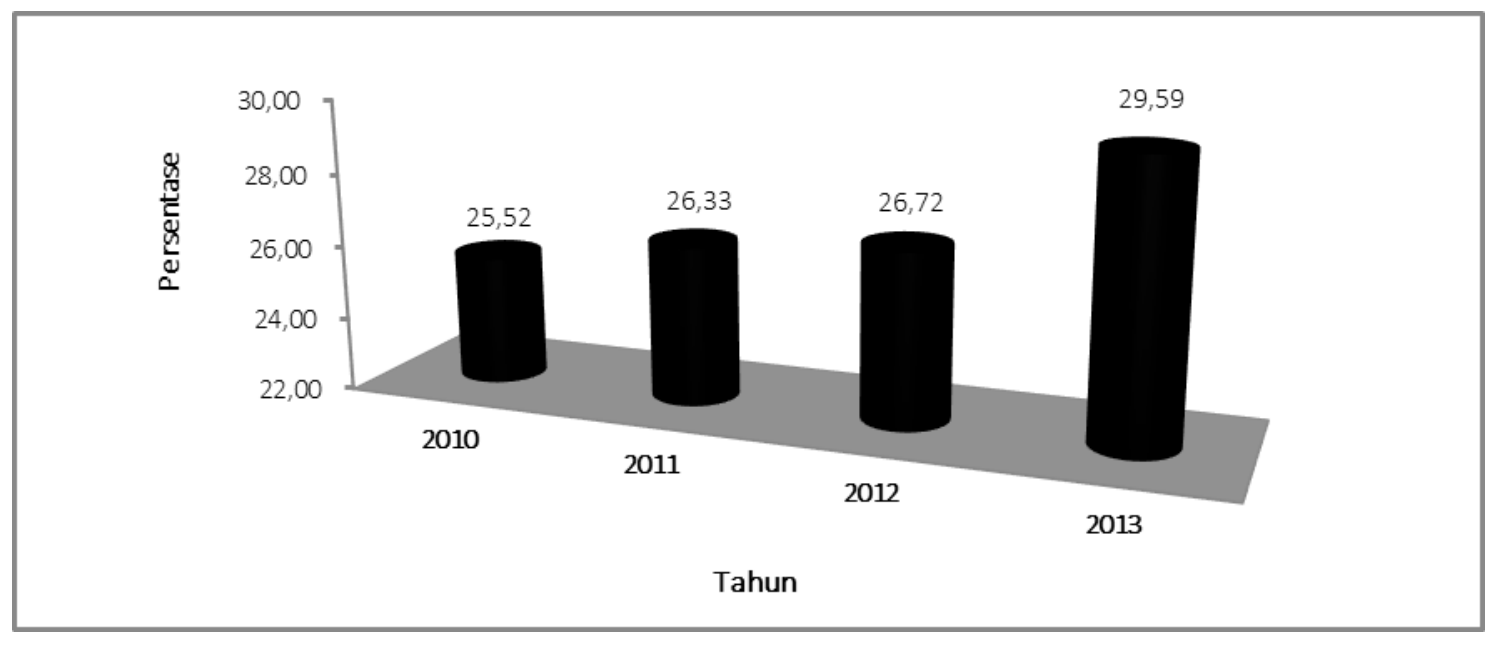

Berdasar gambar 5 diketahui bahwa rasio belanja daerah terhadap PDRB pemerintah daerah kota Bengkulu tahun 2010-2013 cenderung meningkat. Peningkatan rasio ini seiring dengan peningkatan PDRB dan realisasi total belanja, namun pertumbuhan belanja relatif lebih besar yakni mencapai $11,76 \%$ per tahun sedangkan pertumbuhan PDRB/pertumbuhan ekonomi dengan rata-rata sebesar 6,33\% per tahun. Tingginya rasio ini pada tahun 2013 disebabkan oleh tingginya pertumbuhan belanja hingga mencapai $17,85 \%$ dan besarnya nilai ini sebagian besar berasal dari adanya peningkatan belanja modal. 


\section{KESIMPULAN}

Berdasarkan pembahasan tersebut di atas, maka dapat ditarik kesimpulan:

1. Pertumbuhan realisasi belanja pemerintah daerah kota Bengkulu tahun 2011-2013 mengalami fluktuasi dengan pertumbuhan rata-rata $11,76 \%$ per tahun, hal ini tidak seiring dengan pertumbuhan realisasi pendapatan yang cenderung mengalami peningkatan di setiap tahunnya. Trend pertumbuhan belanja operasi cenderung menurun (pertumbuhan rata-rata $12,92 \%$ per tahun) sedangkan pertumbuhan belanja modal, belanja tak terduga dan transfer berfluktuasi dengan rata-rata pertumbuhan masing-masing adalah $17,66 \%$ per tahun, $305,56 \%$ per tahun dan $8,95 \%$ per tahun.

2. Rasio belanja operasi dan belanja modal terhadap total belanja pemerintah daerah kota Bengkulu tahun 2010-2013 memiliki trend yang berlawanan. Rasio belanja operasi terhadap total belanja cenderung mengalami peningkatan dengan rata-rata sebesar $85,20 \%$ per tahun dan rasio ini mendominasi dari total pengeluaran belanja daerah sedangkan rasio belanja modal terhadap total belanja cenderung mengalami penurunan dengan rata-rata sebesar $14,78 \%$ per tahun.

3. Rasio belanja daerah terhadap PDRB pemerintah daerah kota Bengkulu tahun 2010-2013 cenderung mengalami peningkatan dengan rasio rata-rata 27,04\% per tahun. Besaran nilai rasio ini juga dipengaruhi oleh nilai pertumbuhan PDRB dan total belanja. Pertumbuhan total belanja pemerintah daerah Bengkulu relatif lebih tinggi jika dibanding dengan pertumbuhan PDRB.

\section{SARAN}

Saran yang dapat diberikan kepada pemerintah daerah kota Bengkulu diantaranya adalah bahwa kota Bengkulu memiliki pertumbuhan ekonomi yang cukup tinggi, peningkatan pertumbuhan ekonomi dapat terus ditingkatkan dengan peningkatan sumber daya potensial yang dimiliki seperti peningkatan sektor yang memberi kontribusi yang tinggi terhadap perekonomian serta sektor yang menyerap tenaga kerja yang banyak. Sedangkan peningkatan pendapatan daerah dapat dilakukan dengan menggali sumber-sumber penerimaan daerah seperti pendapatan yang bersumber dari Pendapatan Asli Daerah (PAD) sektor pajak daerah dan retribusi daerah. Dengan adanya peningkatan pendapatan, maka alokasi anggaran belanja pemerintah daerah juga akan dapat ditingkatkan khususnya dalam peningkatan layanan publik.

\section{DAFTAR PUSTAKA}

Badan Pusat Statistik. 2014. Katalog BPS 1102001.1771 : Kota Bengkulu Dalam Angka. Badan Pusat Statistik. Kota Bengkulu

Mahmudi. 2010. Laporan Keuangan Pemerintah Daerah: Panduan Bagi Eksekutif, DPRD dan Masyarakat Dalam Pengambilan Keputusan Ekonomi, Sosial dan Politik. UPP STIM YKPN. Yogyakarta.

Nordiawan, Deddi. 2007. Akuntansi Pemerintahan. Salemba Empat. Jakarta

Republik Indonesia. Peraturan Menteri Dalam Negeri Nomor 13 Tahun 2006 Tentang Pedoman Pengelolaan Keuangan Daerah.

,Undang-Undang Republik Indonesia Nomor 23 Tahun 2014 Tentang Pemerintahan Daerah. 